Research article

\title{
ANALYSIS OF HEAVY METALS CONCENTRATION IN TISSUES OF THREE DIFFERENT FISH SPECIES INCLUDED IN HUMAN DIET FROM DANUBE RIVER, IN THE BELGRADE REGION, SERBIA
}

\author{
MILANOV Đ Raša ${ }^{1}$, KRSTIĆ P Milena,, ${ }^{2,}$ MARKOVIĆ V Radmila², \\ JOVANOVIĆ A Dragoljub², BALTIĆ M Branislav², IVANOVIĆ S Jelena², \\ JOVETIĆ Milica³, BALTIĆ Ž Milan ${ }^{2}$
}

\begin{abstract}
${ }^{1}$ Ministry of Health Republic of Serbia, Omladinskih brigada 1, 11000 Belgrade, Serbia; ${ }^{2}$ Faculty of Veterinary Medicine, Bulevar Oslobodjenja 18, 11000 Belgrade, Serbia; ${ }^{3}$ Centre for Food Analysis, Zmaja od Noćaja 11, 11000 Belgrade, Serbia
\end{abstract}

(Received 27 August 2015; Accepted 15 January 2016)

The aim of this study was the investigation of water, sediments and fish tissues contamination with heavy metals. All samples were taken from the Danube River in Belgrade region, a location upstream from Batajnica. Concentrations of $\mathrm{Cd}, \mathrm{Hg}$ and $\mathrm{Pb}$ in water samples were not detected, while concentrations of $\mathrm{Zn}, \mathrm{Fe}, \mathrm{Cu}$ and $\mathrm{As}$ were in the range of $0.004-0.330 \mathrm{mg} \mathrm{L}^{-1}$. Iron was the most deposited metal in sediment samples in contrast to water samples where all investigated metals were detected. For the purpose of heavy metals determination in fresh fish tissue, fifteen samples of three different fish species, silver carp (Hypophthalmichthys molitrix), common carp (Cyprinus carpio) and wels catfish (Silurus glanis) were collected. Concentrations of $\mathrm{Pb}, \mathrm{Cd}, \mathrm{As}$ and $\mathrm{Hg}$ were determined in the digestive tract, liver and muscle by absorption spectroscopy. The highest concentration of $\mathrm{Pb}$ was in the digestive tract in all three fish species, ranging from 0.036 to $1.518 \mu \mathrm{g} \mathrm{g}^{-1}$, while $\mathrm{Cd}$ was mostly deposited in the liver. Concentrations of As were in the range of $0.36-0.73 \mu \mathrm{g} \mathrm{g}^{-1}$ in Hypophthalmichthys molitrix, $0.013-0.18$ $\mu \mathrm{g} \mathrm{g} \mathrm{g}^{-1}$ in Cyprinus carpio and $0.003-0.005 \mu \mathrm{g} \mathrm{g}^{-1}$ in Silurus glanis tissues, while the content of $\mathrm{Hg}$ was equal in all tested tissues of carp. Concentrations of all metals were found to be present in the fish samples at different levels, but these values are under the maximum residual levels prescribed by the European Union (EU) and the maximum allowed concentrations (MAC) for Serbia, so the fish meat is acceptable for the human consumption.

Key words: heavy metals, bioaccumulation, sediments, fish, Danube river

\section{INTRODUCTION}

One of the most common environmental pollutants are heavy metals equally undesirable in the air, water and soil in higher concentrations. Heavy metals in the 
environment are present due to anthropogenic and biogenic sources, which both have undeniable consequences [1]. One of the major problems today is the presence of environmental pollutants in aquatic ecosystems, especially heavy metals. In the aquatic system, they can be deposited into sediments mainly as non-biodegradable pollutants [2-4]. Metal pollutants present in water can accumulate in aquatic organisms from water, sediments or through the food chain [5-10]. Some metals like $\mathrm{Cu}, \mathrm{Zn}$ or Fe are also important for many biochemical processes in living organisms and they are essential elements for aquatic plants and animals [11]. However, in the case of higher concentrations of those metals, they also become toxic and considered as pollutants. The results of many researches show bioaccumulation of metal pollutants from the water in various tissues of aquatic organisms [12-15]. Various species of fish can be bioindicators of contamination with heavy metals and others pollutants [16]. Feeding habits have a great influence on pollutants accumulation, especially regarding heavy metals in different fish species [17-20]. Additionally, in different fish species heavy metals can be deposited in various amounts in their tissues. There are five potential routes for a pollutant to enter fish: via food, non-food particles, gills, oral consumption of water, and the skin [21]. Distribution of these pollutants depends on fish tissue affinity to metals, degree of uptake and accumulation, as well as the ability to be excreted from the organisms. A serious problem with heavy metals is their long biological half-life in living organisms [22]. Gills, liver and kidneys accumulate heavy metals at higher concentration, while muscles contain lower quantities of heavy metal, what is in agreement with the vital function of these tissues. Since it is known that fish presents protein food all around the world, toxic effects of heavy metal presence in their body can result in hazardous effects on human health [11].

The River Danube is an international river, the second largest river in Europe, passing through ten countries; it flows about $588 \mathrm{~km}$ through Serbia. The River Danube is an important transport route, but it is also significant for commercial fishing [23]. The presence of pollutants in the Danube River was in the focus of many previous studies $[10,22,24]$ as well as of the Danube Convention by the International Commission for the Protection of the Danube River. Serbia is a full member of this association since 2003 that includes monitoring of water as well as ecosystem quality [6,25]. It is necessary to follow concentrations of toxic substances, organic contaminants and inorganic, as heavy metals in order to reduce pollution and to provide good ecological status.

The aim of this study is to determine the concentrations of heavy metals in different samples (water, sediments, fish tissues) from the River Danube in populated areas as an indicator of environmental pollution. This work sets the following goals: determination of heavy metals concentrations in water, sediments and fish tissues samples from the River Danube in Serbia, Belgrade region, as well as distribution of heavy metals among various fish tissues (liver, muscle and digestive tracts) of three fish species (silver carp (Hypophthalmichthys molitrix), common carp (Cyprinus carpio) and wels catfish (Silurus glanis)). 


\section{MATERIALS AND METHODS}

\section{Study area}

All samples for this research were taken from the River Danube in the Belgrade region, near Batajnica (Fig. 1). In this part of Serbia, the Danube River passes through agricultural areas and near the locality where the Tisa River flows into the Danube. This point is located about $36 \mathrm{~km}$ upstream from Belgrade, a place known as Belegiš

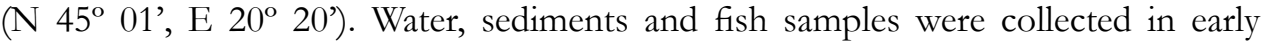
autumn in 2012.

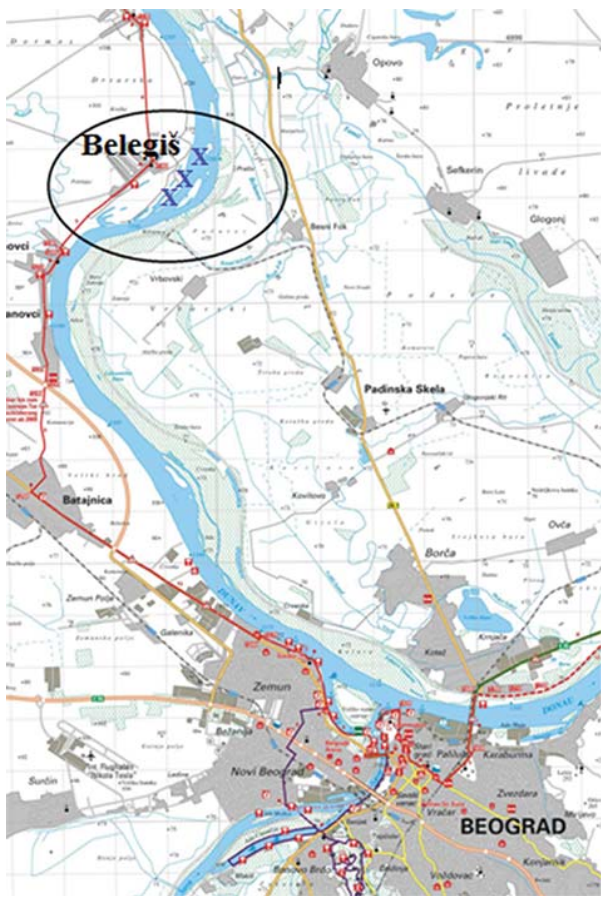

Fig. 1 Map of the sampling area

\section{Reagents}

All reagents used in the analysis were of reagent grade. Double-deionized water (18.2 $\mathrm{M} \Omega \mathrm{cm}^{-1}$ resistivity at $25{ }^{\circ} \mathrm{C}$ ), obtained using a Milli-Q system (Millipore, Bedford, USA), was used for all dilutions. Chemicals for microwave digestion, nitric acid, $\mathrm{HNO}_{3}$ $(65 \%)$ and hydrogen peroxide, $\mathrm{H}_{2} \mathrm{O}_{2}(30 \%)$ were of high pure quality (Merck). The element standard solutions from (Merck) that were used for the calibrations were prepared by diluting stock solutions of $1000 \mathrm{mg} \mathrm{L}^{-1}$. 


\section{Apparatus}

The sample digestion was carried out using a microwave closed system Berghof MWS2 (Berghof Products + Instruments GmbH, Eningen, Germany). After digestion, the concentrations of heavy metals were analyzed by absorption spectroscopy using a GBC 932 plus atomic absorption spectrometer (GBC Scientific Equipment, USA). Detection of $\mathrm{Cu}, \mathrm{Fe}, \mathrm{Zn}$ and $\mathrm{Ni}$ was determined in air-acetylene flame, while analyses of $\mathrm{Pb}$ and $\mathrm{Cd}$ were performed by graphite furnace method (GBC SensAA spectrometer with Hyper-Pulse background corrector) with an auto sampler. Mercury and arsenic were analyzed by the cold vapor technique with a flow injection system. The operating parameters for the working elements were set as recommended by the manufacturers as given in Table 1. All digested samples were analyzed three times for each metal. The atomic absorption signal was measured in peak area mode against a calibration curve.

Table 1. Instrumental analytical conditions of measurement of heavy metals for FAAS

\begin{tabular}{|c|c|c|c|c|}
\hline Element & Acetylene $\left(\mathrm{L}\right.$ min $\left.^{-1}\right)$ & $\operatorname{Air}\left(L \min ^{-1}\right)$ & Wavelength (nm) & Slit width (nm) \\
\hline $\mathrm{Fe}$ & 2.0 & 17.0 & 248.3 & 0.2 \\
\hline $\mathrm{Cu}$ & 2.0 & 17.0 & 324.7 & 0.5 \\
\hline $\mathrm{Zn}$ & 2.0 & 17.0 & 213.9 & 0.5 \\
\hline As & 2.0 & 17.0 & 193.7 & 1.0 \\
\hline $\mathrm{Hg}$ & 2.0 & 17.0 & 253.7 & 1.0 \\
\hline \multicolumn{3}{|c|}{ Instrumental conditions } & $\mathrm{Pb}$ & Cd \\
\hline \multicolumn{3}{|c|}{ Wavelength (nm) } & 217.0 & 228.8 \\
\hline \multicolumn{3}{|c|}{ Slit width (nm) } & 1.0 & 0.5 \\
\hline \multicolumn{3}{|c|}{ Argon flow $\left(\mathrm{mL} \mathrm{min}{ }^{-1}\right)$} & 250 & 250 \\
\hline \multicolumn{3}{|c|}{ Sample volume $(\mu \mathrm{L})$} & 20 & 20 \\
\hline \multicolumn{5}{|c|}{ Heating program temperature $\left({ }^{\circ} \mathrm{C}\right)$} \\
\hline \multicolumn{3}{|c|}{ Drying 1} & $80(10,10)^{\mathrm{a}}$ & $80(10,10)$ \\
\hline \multicolumn{3}{|l|}{ Drying 2} & $120(20,5)$ & $120(20,5)$ \\
\hline \multicolumn{3}{|c|}{ Pyrolysis } & $400(5,15)$ & $300(5,15)$ \\
\hline \multicolumn{3}{|c|}{ AZ (auto zero) } & $400(0.5,1)$ & $300(0.5,1)$ \\
\hline \multicolumn{3}{|c|}{ Atomization } & $1600(1,2)$ & $1700(0.9,2)$ \\
\hline \multicolumn{3}{|c|}{ Cleaning } & $2100(1,1)$ & $2100(1,1)$ \\
\hline
\end{tabular}

Conditions for GFAAS a - ramp time (s), hold time (s)

\section{Sampling}

Water samples $(\mathrm{n}=10)$ were taken from approximately $20-30 \mathrm{~cm}$ below the water surface nearby the river bank with a $5 \mathrm{~L}$ Freidinger bottle and mixed. $500 \mathrm{~mL}$ subsamples were bottled in pre-cleaned plastic flasks. The sample material was stored in darkness at a temperature of approximately $4{ }^{\circ} \mathrm{C}$ and before analyses all water samples were filtered through Whatman filters to remove suspended particulate matter. Ten samples of sediments were obtained by Ekman grab from a depth of $1 \mathrm{~m}$ on the margin of the 
bank. The sediments were sampled, quickly mixed in the field and amounts of about $200 \mathrm{~g}$ were stored at $4{ }^{\circ} \mathrm{C}$ in metal free plastic bags.

In the aim to determine heavy metals in fish tissue, fifteen samples of three different fish species, silver carp (Hypophthalmichthys molitrix), common carp (Cyprinus carpio) and wels catfish (Silurus glanis) were collected. The samples were caught by professional fishermen during early autumn of 2012 from the Danube River near Belegiš. Each fish from the catch was identified to species level and a random sub-sample of fifteen individuals per species was used for metal analysis. As the juveniles of these species $(<90 \mathrm{~mm}$ total length) could not be reliably identified, they were excluded from the analysis. The fifteen fresh fish used for metal analyses were euthanized with an overdose of MS-222 (3-aminobenzoic acid ethyl ether, Sigma-Aldrich $\AA$, see [26]) for details), weighed with accuracy of $0.01 \mathrm{~g}$ (total body wet weight, WT) (OHAUS Pioneer, Parsippany, UK) transported in refrigerator at $5{ }^{\circ} \mathrm{C}$ to the laboratory daily. The total body weight of Hypophthalmichthys molitrix, Cyprinus carpio and Silurus glanis were $7.80 \pm 2.54 \mathrm{~kg}, 4.53 \pm 1.89 \mathrm{~kg}$ and $3.07 \pm 1.03 \mathrm{~kg}$, respectively.

Fish were dissected and then, a sample of muscle (cca. $500 \mathrm{mg}$ ) below the dorsal fin, the digestive tract and the whole liver were stored for metal analyses in polypropylene vials (previously pre-cleaned with nitric acid (10\%) and rinsed three times in deionised water) at $-20^{\circ} \mathrm{C}$. Fish muscle was selected as the target tissue in order to determine the risk posed by metal pollution to humans, while liver and digestive tract were selected because they represent key organs in detoxification processes, as well as target organs for certain metals accumulation from ecosystem.

\section{Heavy metals analysis}

The samples of sediments were first dried at $110{ }^{\circ} \mathrm{C}$ for $24 \mathrm{~h}$ and then mechanically homogenizated to obtain a powder. Approximately $0.5 \mathrm{~g}$ of each dry sediment sample were wet digested with nitric acid and hydrogen peroxide in a microwave closed system using temperature program $180-240^{\circ} \mathrm{C}$ during 35 min.

For determination of heavy metal contents in freeze-dried fish samples, about $1 \mathrm{~g}$ of fish tissues was homogenized and digested with acid in the same way as sediments in a microwave oven. Samples were diluted to a final volume of $25 \mathrm{~mL}$ with double deionized water after digestion. At the same time, a blank trial was carried out. Metal concentrations were determined on wet weight basis as milligram of element per kilogram of sediment or water sample, while heavy metal contents in fish tissues were expressed as microgram of metal per gram of dry weight sample. Limits of detection of heavy metals in water samples were for $\mathrm{Pb}, \mathrm{Cd}, \mathrm{Hg}$ and $\mathrm{As} 0.009,0.008,0.005$ and $0.5 \mathrm{mg} \mathrm{kg}^{-1}$, respectively, while detection limits in fish tissues samples were $0.04,0.05$, $0.02,0.02$ and $0.05 \mathrm{mg} \mathrm{kg}^{-1}$ for $\mathrm{Pb}, \mathrm{Cd}$, As and $\mathrm{Hg}$, respectively.

The analysis was performed involving the assessment of concentrations of the following elements: $\mathrm{As}, \mathrm{Hg}, \mathrm{Pb}$ and $\mathrm{Cd}$. The concentrations in fish meat (i.e muscle samples) were also recalculated to wet tissue weight (ww) and compared with the 
maximum allowed concentrations (MAC) in fish meat for the utilization in human diets as established by the Europea Union (EU) and the national legislation. According to the EU legislation (European Commission Regulation, 2006), MAC for Cd, $\mathrm{Hg}$ and $\mathrm{Pb}$ are $0.05,0.5$ and $0.30 \mu \mathrm{g} \mathrm{g}^{-1} \mathrm{ww}$, respectively. The national legislation prescribed $\mathrm{MAC}$ for $\mathrm{Cd}, \mathrm{Hg}, \mathrm{Pb}$ and $\mathrm{As}$ in fish meat at $0.05,0.5,0.3$ and $2.0, \mu \mathrm{g} \mathrm{g} \mathrm{g}^{-1} \mathrm{ww}$, respectively (Official Gazette of RS 2012).

\section{Statistical analysis}

All samples were collected and analyzed in duplicate and the results obtained as the mean \pm standard deviation. The statistical analysis was performed using Student's t-test for significance and analysis of variance (ANOVA) with the multiple comparisons Turkey's test to determine the significant difference between treated means. In all cases, the estimation was carried out at significant level of 0.01 and 0.05 .

\section{RESULTS}

The concentrations of cadmium, mercury and lead in water samples from the River Danube were below the limit of detection (Table 2). Concentrations of $\mathrm{Cd}, \mathrm{Hg}$ and $\mathrm{Pb}$ in water samples were not detected, while concentrations of $\mathrm{Zn}, \mathrm{Fe}, \mathrm{Cu}$ and As were in the range $0.004-0.330 \mathrm{mg} \mathrm{L}^{-1}$. For a preliminary risk assessment, the content of metals were compared with Serbian regulations for limit values of pollutant substances in surface, groundwater and sediment [29].

Table 2. Heavy metal concentrations in water samples (mg L-1) of Danube River compared to limit values for different class of water provided by Serbian regulations (2012)

\begin{tabular}{cccc}
\hline Metal & Detection values & $\begin{array}{c}\text { Water }\left(\mathbf{m g ~ L}^{-1}\right) \\
\text { Limit values class I }\end{array}$ & Limit values class II \\
\hline $\mathrm{Zn}$ & $0.032 \pm 0.002$ & 0.030 & 0.300 \\
$\mathrm{Fe}$ & $0.330 \pm 0.020$ & 0.200 & 0.500 \\
$\mathrm{Cu}$ & $0.004 \pm 0.001$ & 0.005 & 0.022 \\
$\mathrm{As}$ & $0.004 \pm 0.001$ & $<0.005$ & 0.010 \\
$\mathrm{Cd}$ & $\mathrm{ND}$ & $\mathrm{NA}$ & $\mathrm{NA}$ \\
$\mathrm{Hg}$ & $\mathrm{ND}$ & $\mathrm{NA}$ & $\mathrm{NA}$ \\
$\mathrm{Pb}$ & $\mathrm{ND}$ & $\mathrm{NA}$ & $\mathrm{NA}$ \\
\hline
\end{tabular}

$\mathrm{ND}$ - no detection, NA - not allowed

The concentrations of heavy metals in the sediment samples of the River Danube are presented in Table 3. They were also compared to Target and limit values of Serbian regulations for limit values of pollutant substances in surface, groundwater and sediment [29]. 
Table 3. Content of heavy metals in sediments $\left(\mathrm{mg} \mathrm{kg}^{-1}\right)$ of Danube River compared with Target and Limit values of Serbian regulations (2012)

\begin{tabular}{cccc}
\hline \multirow{2}{*}{ Metal } & \multicolumn{3}{c}{ Sediment $\left(\mathrm{mg} \mathrm{kg}^{-1}\right)$} \\
\cline { 2 - 4 } & Detection values & Target values & Limit values \\
\hline $\mathrm{Zn}$ & $139.40 \pm 8.71$ & 140 & 430 \\
$\mathrm{Fe}$ & $16104 \pm 1068$ & $/$ & $/$ \\
$\mathrm{Cu}$ & $35.95 \pm 1.40$ & 36 & 110 \\
$\mathrm{As}$ & $8.90 \pm 0.25$ & 29 & 42 \\
$\mathrm{Cd}$ & $0.61 \pm 0.11$ & 0.8 & 6.4 \\
$\mathrm{Hg}$ & $0.69 \pm 0.08$ & 0.3 & 1.6 \\
$\mathrm{~Pb}$ & $32.58 \pm 2.61$ & 85 & 310 \\
\hline
\end{tabular}

Concentrations of $\mathrm{Cd}, \mathrm{Hg}$ and $\mathrm{As}$ in sediments were $0.61,0.69$ and $8.90 \mathrm{mg} \mathrm{kg}^{-1}$, respectively while the amount of $\mathrm{Pb}$ was $32.58 \mathrm{mg} \mathrm{kg}^{-1}$, similar to the amount of $\mathrm{Cu}\left(35.95 \mathrm{mg} \mathrm{kg}^{-1}\right)$. Concentrations of zinc and iron were higher, as well as in water samples and indicate a slow precipitation.

Results of heavy metals analyses of these fish species are given in Table 4.

Table 4. Heavy metal concentrations ( $\mu \mathrm{g} \mathrm{g}^{-1}$ dry weight) in tissues of the three fish species expressed as means \pm standard deviation (range)

\begin{tabular}{llllll}
\hline \multirow{2}{*}{ Species } & \multirow{2}{*}{ Tissues } & \multicolumn{4}{c}{ Heavy metal concentrations } \\
\cline { 3 - 6 } & & \multicolumn{1}{c}{$\mathbf{P b}$} & $\mathbf{C d}$ & $\mathbf{H g}$ & As \\
\hline \multirow{3}{*}{$\begin{array}{l}\text { Hypophthalmichthys } \\
\text { molitrix }\end{array}$} & muscle & $0.048^{\mathrm{A}} \pm 0.010$ & $0.014^{\mathrm{B}} \pm 0.002$ & $0.140^{\mathrm{B}} \pm 0.024$ & $0.036^{\mathrm{A}} \pm 0.008$ \\
& digestive tract & $1.518^{\mathrm{A}} \pm 0.019$ & $0.062^{\mathrm{AB}} \pm 0.002$ & $0.253^{\mathrm{A}} \pm 0.052$ & $0.065^{\mathrm{A}} \pm 0.016$ \\
& liver & $0.125^{\mathrm{AB}} \pm 0.018$ & $0.191^{\mathrm{A}} \pm 0.039$ & $0.185^{\mathrm{A}} \pm 0.028$ & $0.073^{\mathrm{A}} \pm 0.014$ \\
\cline { 2 - 6 } Cyprinus carpio & muscle & $0.036^{\mathrm{A}} \pm 0.015$ & $0.014^{\mathrm{A}} \pm 0.004$ & $0.207^{\mathrm{A}} \pm 0.027$ & $0.013^{\mathrm{A}} \pm 0.003$ \\
& digestive tract & $0.266^{\mathrm{A}} \pm 0.029$ & $0.103^{\mathrm{A}} \pm 0.029$ & $0.207^{\mathrm{A}} \pm 0.039$ & $0.016^{\mathrm{A}} \pm 0.004$ \\
& liver & $0.047^{\mathrm{A}} \pm 0.019$ & $0.132^{\mathrm{A}} \pm 0.035$ & $0.206^{\mathrm{B}} \pm 0.039$ & $0.018^{\mathrm{A}} \pm 0.004$ \\
Silurus glanis & muscle & $0.014^{\mathrm{A}} \pm 0.005$ & $0.008^{\mathrm{AB}} \pm 0.003$ & $0.327^{\mathrm{AB}} \pm 0.110$ & $0.003^{\mathrm{A}} \pm 0.001$ \\
& digestive tract & $0.036^{\mathrm{A}} \pm 0.014$ & $0.101^{\mathrm{B}} \pm 0.031$ & $0.167^{\mathrm{A}} \pm 0.043$ & $0.005^{\mathrm{A}} \pm 0.001$ \\
& liver & $0.034^{\mathrm{B}} \pm 0.018$ & $0.064^{\mathrm{A}} \pm 0.016$ & $0.143^{\mathrm{AB}} \pm 0.039$ & $0.004^{\mathrm{A}} \pm 0.001$ \\
\hline
\end{tabular}

$A, B$ and a Significant differences $(p<0.01$ and $p<0.05)$ between the same tissues of the different species.

The highest concentration of $\mathrm{Pb}$ was found in digestive tract of Hypophthalmichthys molitrix, $1.518 \pm 0.019 \mu \mathrm{g} \mathrm{g}^{-1}$, while lower concentration of $\mathrm{Pb}$ was detected in Silurus glanis muscle $\left(0.014 \pm 0.005 \mu \mathrm{g} \mathrm{g}^{-1}\right)$. Distribution of $\mathrm{Pb}$ is the same in all investigated fish species and decreases in a following order: digestive tract $>$ liver $>$ muscle. 
The concentrations of As ranged from 0.36 to $0.73 \mu \mathrm{g} \mathrm{g}^{-1}$ in Hypophthalmichthys molitrix, 0.013-0.18 $\mu \mathrm{g} \mathrm{g}^{-1}$ in Cyprinus carpio and 0.003-0.005 $\mu \mathrm{g} \mathrm{g}^{-1}$ in Silurus glanis tissues. The results show significant difference $(\mathrm{p}<0.01)$ between the same tissues of various species, with the highest deposition of As in tissues of Hypophthalmichthys molitrix.

The significant higher concentrations of $\mathrm{Cd}$ are present in the liver of plankton-feeding fishes (0.132-0.191 $\left.\mu \mathrm{g} \mathrm{g}^{-1}\right)$, while in Silurus glanis liver $0.064 \mu \mathrm{g} \mathrm{g}^{-1}$ was found. This heavy metal was accumulated in low concentration in muscles of all three investigated fish species ranging from 0.008 to $0.014 \mu \mathrm{g} \mathrm{g}^{-1}$. Distribution of $\mathrm{Hg}$ in Cyprinus carpio was the same in all investigated tissues $\left(0.207 \mu \mathrm{g} \mathrm{g}^{-1}\right)$ but in the muscle of Silurus glanis was significantly higher $(\mathrm{p}<0.01)$ compared to the same tissues of two other fish species.

The comparison of heavy metal distribution among various tissues of same species are presented in Fig. 2.
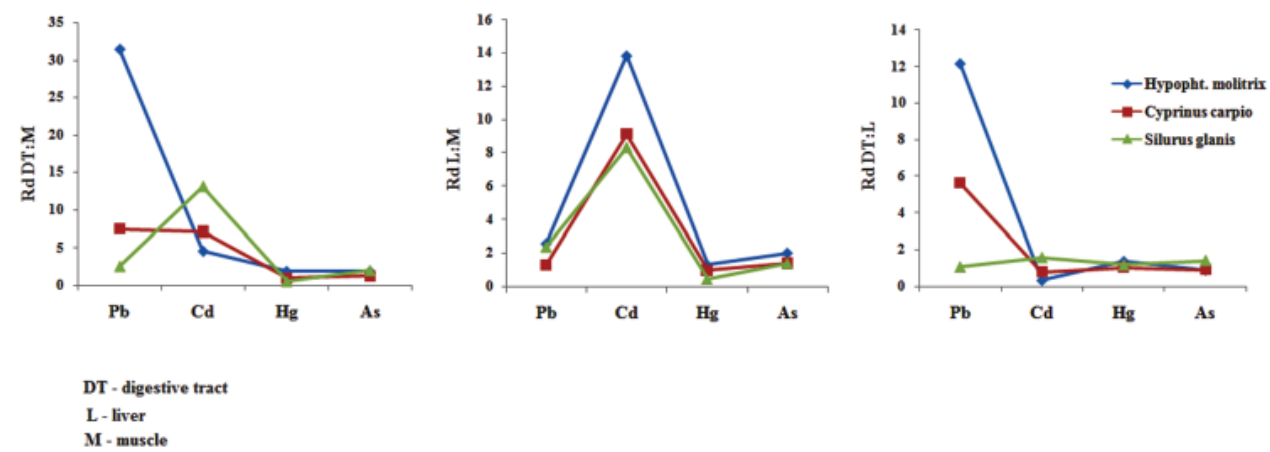

Figure 2. Ratio of heavy metals distribution $(\mathrm{Rd})$ between various tissues among the same species

The most deposited metal in digestive tract is $\mathrm{Pb}$ in Hypophthalmichthys molitrix which is 31.62 times higher than in muscles, while in Silurus glanis this ratio is only 2.57. The concentration of $\mathrm{Cd}$ in digestive tract of Silurus glanis is 12.62 times higher than in muscles, while other two heavy metals show lower ratio between muscles and digestive tract deposition. Analyzing the relation between deposition of heavy metals in liver and muscles spotted the highest ratio in favor of Cd compared to the same distribution of other metals. These ratios in benefit to the liver in Hypophthalmichthys molitrix, Cyprinus carpio and Silurus glanis are 13.64, 9.43 and 8.00, respectively. The $\mathrm{Hg}$ is redistributed in the same way, but ratios between muscle and liver are in range $0.44-1.32$, while this ratio for $\mathrm{Pb}$, in Hypophthalmichthys molitrix is higher than in other two species. Arsenic, as very toxic metal, is present in liver in higher extent than in muscle, with liver to muscle ratio ranging from 1.38 to 2.03 . Distribution ratios between the digestive tract and liver for $\mathrm{Cd}, \mathrm{Hg}$ and $\mathrm{As}$ were below 1.58, with exception of $\mathrm{Pb}$, with the range from 1.06 in Silurus glanis to 12.10 in Hypophthalmichtbys molitrix. 


\section{DISCUSSION}

The presence of heavy metals in water depends on many environmental factors like influence of industry and other forms of pollution. Analysis of water samples has shown the presence of copper and arsenic in traces, while zinc was present in an amount lower than $0.050 \mathrm{mg} \mathrm{L}^{-1}$ as reported for Danube water [25]. The concentration of iron was up to 10 times higher than of other metals in water, while the presence of As in traces makes water polluted. These results are in accordance with previous research of water quality in the River Danube [6]. The mean concentration of arsenic was $0.004 \mathrm{mg} \mathrm{L}^{-1}$ which is lower than the limit for the content of this heavy metal in natural mineral water by FAO and WHO [30]. The metal concentrations in the examined water samples in comparison to the limit values of Serbian regulations [29] indicate the second class of water quality of Danube River. The metal content in the tested water samples does not indicate the pollution of aquatic ecosystems, nor risk to human health.

The order of amounts of metals deposited in samples of sediments from River Danube is $\mathrm{Fe}>\mathrm{Zn}>\mathrm{Cu}>\mathrm{Pb}>\mathrm{As}>\mathrm{Hg}>\mathrm{Cd}$. Samples of sediments were taken in early autumn, after agricultural treatment and these results can be explained by this influence. One of the reasons for these results is the fact that several rivers flow into the Danube near the place where the samples were taken, but also large cities can be serious polluters of the environment, as well as industry. In the analyses of 74 sediments samples taken throughout the length of the watercourse of the River Danube [31], researchers found following metal concentrations: Fe (29 $\left.700 \pm 1900 \mu \mathrm{g} \mathrm{g}^{-1}\right)$, $\mathrm{Cu}\left(65.7 \pm 12.3 \mu \mathrm{g} \mathrm{g}^{-1}\right), \mathrm{Zn}\left(187 \pm 25 \mu \mathrm{g} \mathrm{g}^{-1}\right), \mathrm{Hg}\left(0.22 \pm 0.05 \mu \mathrm{g} \mathrm{g} \mathrm{g}^{-1}\right), \mathrm{Pb}\left(46.3 \pm 6.8 \mu \mathrm{g} \mathrm{g}^{-1}\right)$ that is in accordance our results.

The increased concentration of heavy metals in sediments is the result of higher concentrations of these metals in the water, which is easily adsorbed on the surface of the sediment and poses as an ecological threat to wildlife watercourses. The analysis of the sediments from the River Danube indicates the presence of all tested metals in much higher concentrations than in water, but these results are below target values recommended by Serbian Regulations [29] accept level of $\mathrm{Hg}$ which are below the target and limit value. The presence of metals in sediments is an indicator of the deposition in the river-bed and represents a potential risk to the ecosystem, especially observed mercury concentration. In subsequent investigations of health risk assessment, concentrations of $\mathrm{As}, \mathrm{Cd}, \mathrm{Pb}$ and $\mathrm{Hg}$ were determined in freshwater fish species.

The heavy metals concentrations were variously distributed in fish tissues. The $\mathrm{Pb}$ content in Silurus glanis muscle is low and this result is in agreement with previous research [19]. Two fish species, Hypophthalmichthys molitrix and Cyprinus carpio feed on plankton and algae and it can be one of the reasons for their higher lead bioaccumulation. The variation of accumulation of heavy metals in different fish species is attributed to several feeding habits. Hypophthalmichthys molitrix is typical planktivore and can be 
used as aquatic plant control, while Cyprinus carpio belongs to omnivores [12]. Silurus glanis, as piscivore, is predominantly a nocturnal species, one of the deep freshwater fish. During the day, it is consistently situated in the coastal zone, where it spends time hidden in concealed habitats. These feeding habits have a great influence in heavy metals deposition in fish tissues.

Significantly higher concentrations of $\mathrm{Cd}$ are present in the liver of plankton-feeding fishes, while in Silurus glanis liver was found a lower concentration. The accumulation of $\mathrm{Cd}$ in the liver is shown in several studies [12,32,33]. However, higher concentration of $\mathrm{Cd}$ in the digestive tract of Silurus glanis is in accordance with its feeding habits confirming the presence of $\mathrm{Cd}$ in the sediment. The $\mathrm{Hg}$ content is higher in all tissues in all investigated species. Mercury is the one of the very toxic metals with a tendency to bind to the sulfide group of proteins and deposits in muscles [33] that can explane the highest concentration of $0.327 \pm 0.110 \mu \mathrm{g} \mathrm{g} \mathrm{g}^{-1}$ in muscles of Silurus glanis. The concentration of $\mathrm{Hg}$ is equal in all tested tissues of carp, while the presence of this heavy metal is significantly lower $(\mathrm{p}<0.01)$ in the muscle of Hypophthalmichthys molitrix than in other tissues. This results contrary previous research [19] which connects feeding habits with heavy metals deposition in muscles but could be explaned by different tissue samples and fish species. The Commission of the European Communities [27] established the maximum levels of heavy metals in fish muscles and only in Silurus glanis muscle tissue mercury was detected $\left(0.327 \mu \mathrm{g} \mathrm{g}^{-1}\right)$ in concentration close to proposed concentration for mercury in muscle meat of fish $\left(0.5 \mathrm{mg} \mathrm{kg}^{-1}\right.$ of wet weight of sample).

The highest concentration of As was in tissues of Hypophthalmichthys molitrix which is in accordance with the results in a previous research of Danube fish [34]. However, in the present study, As levels were lower than those reported in other studies, including As in the range of $0.021-0.048 \mu \mathrm{g} \mathrm{g}^{-1}$ for Cyprinus carpio [19]. These concentrations of As can be explained by the presence of As in water, which means that As was present in higher concentrations in planktons and algae, as well as in plankton-feeding fish tissues.

At least, the lead concentration decreases in the following order: digestive tract $>$ liver $>$ muscle in all three fish species and this distribution also applies for mercury concentrations in Hypophthalmichthys molitrix, as well as for cadmium and arsenic contents in Silurus glanis. The highest concentrations of cadmium and arsenic were deposited in the liver tissue of Hypophthalmichthys molitrix and Cyprinus carpio, while in the muscle of Silurus glanis a high concentration of mercury was found. These results indicate a remarkable contribution of these species to the intake of these metals, but these values of heavy metal contents are also below the maximum permitted concentrations of these pollutants according to the Commission of the European Communities (EC), hence fish can be acceptable for human consumption. It is also known that fish is economically viable in the human diet [35]. Considering all these results, it is necessary to monitor the presence of heavy metals as environmental 
pollutants in the future, thus ensuring a good ecological status of the Danube river, as well as providing healthy and safe fresh fish.

\section{Acknowledgements}

The study was supported by the Ministry of Education, Science and Technological Development of the Republic of Serbia [Project number 31011].

\section{Authors' contributions}

RM participated in the design of the experiment. MK, DJ and MJ participated in the analytical chemical methods and drafted the manuscript. RM participated in the interpretation of results. BB participated in the organization of the experiment and sampling. JI participated in the design of the study and performed the statistical analysis. MB conceived of the study, and participated in its design, coordination of the experiment and helped to draft the manuscript.

\section{Declaration of conflicting interests}

The author(s) declared no potential conflicts of interest with respect to the research, authorship, and/or publication of this article.

\section{REFERENCES}

1. Ajeagah GA, Cioroi M, Praisler M, Constantin O, Palela M, Bahrim G: An Ecological Assessment of the Pollution Status of the Danube River Basin in the Galati RegionRomania. J Water Res Protect 2013, 5: 876 - 886.

2. Milenković N, Damjanović M, Ristić M: Study of Heavy Metal Pollution in Sediments from the Iron Gate (Danube River), Serbia and Montenegro. Polish J Environmen Stud 2005, 14: 781-787.

3. Vuković Ž, Vuković D, Radenković M, Stanković S: A new approach to the analysis of the accumulation and enrichment of heavy metals in the Danube River sediment along the Iron Gate reservoir in Serbia. J Serb Chem Soc 2012, 77: 381-392.

4. Vuković D., Vuković Ž., Stanković S. 2014 - The impact of the Danube Iron Gate Dam on heavy metal storage and sediment flux within the reservoir - Catena 113: 18-23.

5. Ajmal M, Uddin R, Khan AU: Heavy metals in water, sediments, plants and fish of Kali NadiU.P. (India). Environment International 1988, 14: 515-523.

6. Pajević S, Borišev M, Rončević S, Vukov D, Igić R: Heavy metal accumulation of Danube river aquatic plants - indication of chemical contamination. Cent Eur J Biol 2008, 3: 285294.

7. Mendil D, Unal OF, Tuzen M, Soylak M: Determination of trace metals in different fish species and sediments from the River Yesilırmak in Tokat, Turkey. Food Chem Toxicol 2010, 48: 1383-1392. 
8. Dukowska M, Michalowicz J, Grzybkowska M: Influence of natural organic matter and metal accumulation in sediment on reverine macrobenthic assemblages. Pol J Ecol 2012, 60: 351-362.

9. Squadrone S, Prearo M, Brizio P, Gavinelli S, Pellegrino M, Scanzio T, Guarise S, Benedetto A, Abete MC: Heavy metals distribution in muscle, liver, kidney and gill of European catfish (Silurus glanis) from Italian Rivers. Chemosphere 2013, 90: 358-365.

10. Subotić S, Višnjić-Jeftić Ž, Spasić S, Hegediš A, Krpo-Ćetković J, Lenhardt M: Distribution and accumulation of elements ( $\mathrm{As}, \mathrm{Cu}, \mathrm{Fe}, \mathrm{Hg}, \mathrm{Mn}$, and $\mathrm{Zn}$ ) in tissues of fish species from different trophic levels in the Danube River at the confluence with the Sava River (Serbia). Environ Sci Pollut Res 2013, 20: 5309-5317.

11. Akan JC, Mohmoud S, Yikala BS, Ogugbuaja VO: Bioaccumulation of Some Heavy Metals in Fish Samples from River Benue in Vinikilang, Adamawa State, Nigeria. Am J Anal Chem 2012, 3: 727-736.

12. Has-Schön E, Bogut I, Strelec I: Heavy Metal Profile in Five Fish Species Included in Human Diet, Domiciled in the End Flow of River Neretva (Croatia). Arch Environ Contam Toxicol 2006, 50: 545-551.

13. Djedjibegović J, Larssen T, Skrbo A, Marjanović A, Sober M: Contents of cadmium, copper, mercury and lead in fish from the Neretva river (Bosnia and Herzegovina) determined by inductively coupled plasma mass spectrometry (ICP-MS). Food Chem 2012, 131: 469-476.

14. Noel L, Chekri R, Millour S, Merlo M, Leblanc JC, Guerin T: Distribution and relationships of $\mathrm{As}, \mathrm{Cd}, \mathrm{Pb}$ and $\mathrm{Hg}$ in freshwater fish from five French fishing areas. Chemosphere 2013, 90: 1900-1910.

15. Monroy M, Maceda-Veiga A, Sostoa A: Metal concentration in water, sediment and four fish species from Lake Titicaca reveals a large-scale environmental concern. Sci Total Environ 2014, 478: 233-244.

16. Dural M, Goksu MZL, Ozak AA: Investigation of heavy metal levels in economically important fish species captured from the Tuzla lagoon. Food Chem 2007, 102: 415-421.

17. Amundsen P, Staldvik FJ, Lukin AA, Kashulin NA, Popova OA, Reshetnikov YS: Heavy metal contamination in freshwater fish from the border region between Norway and Russia. Sci Total Environ 1997, 201: 211-224.

18. Cheng Z, Chen K, Li K, Nie X, Wu SC, Kong C, Wong C, Wong M: Arsenic contamination in the freshwater fish ponds of Pearl River Delta: bioaccumulation and health risk assessment. Environ Sci Pollut Res 2013, 20: 4484-4495.

19. Zrnčić S, Oraić D, Ćaleta M, Mihaljević Ž, Zanella D, Bilandžić N: Biomonitoring of heavy metals in fish from the Danube River. Environ Monit Assess 2013, 185: 1189-1198.

20. Merciai R, Guasch H, Kumar A, Sabater S, García-Berthou E: Trace metal concentration and fish size: Variation among fish species in a Mediterranean river. Ecotox Environ Safe 2014, 107: 154-161.

21. Nussey G, Vuren JHJ, Preez HH: Bioaccumulation of chromium, manganese, nickel and lead in the tissues of the moggel, Labeo umbratus (Cyprinidae), from Witbank Dam, Mpumalanga. Water SA 2000, 26: 269-284.

22. Antonijević MD, Arsović M, Čáslavský J, Cvetković V, Dabić P, Franko M, Ilić G, Ivanović M, Ivanović N, Kosovac M, Medić D, Najdanović S, Nikolić M, Novaković J, Radovanović T, Ranić Dj, Šajatović B, Špijunović G, Stankov I, Tošović J, Trebše P, Vasiljević O, Schwarzbauer J: Actual contamination of the Danube and Sava rivers at Belgrade. J Serb Chem Soc 2013, 9:1169-1184. 
23. Višnjić-Jeftić Ž, Jarić I, Jovanović Lj, Škorić S, Smederevac-Lalić M, Nikčević M, Lenhardt M: Heavy metal and trace element accumulation in muscle, liver and gills of the Pontic shad (Alosa immaculata Bennet 1835) from the Danube River (Serbia). Microchem J 2010, 95: 341-344.

24. Bastić Lj, Kočovski T, Antonović D, Vidarić D: The meat quality of some freshwater fishnutritive and technological aspects. Acta Vet 2002, 52: 259-266.

25. Pantelica A, Ene A, Georgescu II: Instrumental neutron activation analysis of some fish species from Danube River in Romania. Microchem J 2012, 103: 142-147.

26. Noga E.J. Fish disease: diagnosis and treatment. 2010, John Wiley and Sons.

27. The Commission of the European Communities: Commission Regulation (EC) No $1881 / 2006$ of 19 December 2006 setting maximum levels for certain contaminants in foodstuffs. Official J Eur Union 2006, L364: 0005-0024.

28. Regulation on quantity of pesticides, metals, metalloids, and other toxic substances, chemotherapeutics, anabolics, and other substances which can be found in food. - Official Gazzette of RS, No 29/2014, 37/2014-corr. and 39/2014.

29. Regulation of limit values for pollutants in surface and ground waters and sediments, and the deadlines for their achievement. Official Gazzette of RS, 50/2012.

30. Codex Alimentarius Commissione: Joint FAO/WHO food standards programe Codex committee on contaminants in food, Sixth Session, Maastricht, The Netherlands, $26-30$ March 2012.

31. Woitke P, Wellmitz J, Helm D, Kube P, Lepom P, Litheraty P: Analysis and assessment of heavy metal pollution in suspended solids and sediments of the River Danube. Chemosphere 2003, 51: 633-642.

32. Jarić I,Višnjić-Jeftić Ž, Cvijanović G, Gačić Z, Jovanović Lj, Skorić S, Lenhardt M: Determination of differential heavy metal and trace element accumulation in liver, gills, intestine and muscle of sterlet (Acipenser ruthenus) from the Danube River in Serbia by ICP-OES. Microchem J 2011, 98: 77-81.

33. Castro-Gonzalez MI, Mendez-Armenta M: Heavy metals: Implications associated to fish consumption. Environ Toxicol Phar 2008, 26:263-271.

34. Lenhardt M, Jarić I, Višnjić-Jevtić Ž, Skorić S, Gačić Z, Pucar M, Hegediš A: Concentrations of 17 elements in muscle, gills, liver and gonads of five economically important fish species from the Danube River. Knowl Managt Aquatic Ecosyst 2012, 407: 1-10.

35. Tešić M, Baltić M, Teodorović V, Nedić D, Mirilović M, Marković R, Aleksić-Angelis A: Effects of various meal compositions on production results, economic performances and fish meat quality. Acta Vet - Beograd 2014, 64: 338-348. 


\section{ISPITIVANJE KONCENTRACIJE TEŠKIH METALA U TKIVIMA TRI RAZLIČITE VRSTE RIBA IZ DUNAVA SA PODRUČJA BEOGRADA KOJE SE KORISTE U ISHRANI LJUDI}

MILANOV Đ Raša, KRSTIĆ P Milena, MARKOVIĆ V Radmila, JOVANOVIĆ A Dragoljub, BALTIĆ M Branislav, IVANOVIĆ S Jelena, JOVETIĆ Milica, BALTIĆ Ž Milan

Cilj ovog rada je ispitivanje kontaminacije teškim metalima vode, sedimenta kao i tri različite vrste sveže ribe. Svi uzorci su uzeti iz Dunava u regionu Beograda, tačnije uzvodno od Batajnice. Koncentracije $\mathrm{Cd}, \mathrm{Hg}$ i $\mathrm{Pb}$ u uzorcima vode su približne graničnim vrednostima detekcije, dok su koncentracije Zn, Fe, Cu i As u opsegu 0.004 - $0.330 \mathrm{mg} \mathrm{L}^{-1}$. Gvožđe je najprisutniji metal u uzorcima sedimenata za razliku od uzoraka vode gde su svi ispitivani metali podjednako zastupljeni. U cilju ispitivanja teških metala u tkivima riba sakupljeno je po petnaest uzoraka tri različite vrste riba, tolstolobika (Hypophthalmichthys molitrix), šarana (Cyprinus carpio) i soma (Silurus glanis). Koncentracije $\mathrm{Pb}, \mathrm{Cd}$, As i $\mathrm{Hg}$ određene su u digestivnom traktu, jetri i mišićnom tkivu sveže dunavske ribe metodom absorpcione spektroskopije. Najveća koncentracija $\mathrm{Pb}$ zabeležena je u digestivnom traktu kod svih ispitivanih vrsta riba i to u opsegu 0.036 $1.518 \mu \mathrm{g} \mathrm{g}{ }^{-1}$, dok je Cd uglavnom deponovan u jetri. Koncentracija As bila je u opsegu $0.36-0.73 \mu \mathrm{g} \mathrm{g}^{-1} \mathrm{u}$ tkivu Hypophthalmichthys molitrix, $0.013-0.18 \mu \mathrm{g} \mathrm{g} \mathrm{g}^{-1} \mathrm{u}$ tkivu Cyprinus carpio i $0.003-0.005 \mu \mathrm{g} \mathrm{g}^{-1}$ u tkivu Silurus glanis, dok je sadržaj Hg bio izjednačen u svim ispitivanim tkivima šarana. Koncentracije svih metala u tkivima riba su različite $i$ ispod maksimalno dozvoljenih koncentracija predvidjenih pravilnikom Evropske Unije i maksimalno dozvoljenih koncentracije (MDK) u Srbiji, a riba može da se koristi za ishranu ljudi. 